\title{
Elektromos motorok elektromágneses és dinamikai jellemzőinek mérésére alkalmas mérőrendszer tervezése
}

\section{Design of a Measuring System Suitable for Measuring the Electromagnetic and Dynamic Characteristics of Electric Motors}

\author{
Szántó Attila, ${ }^{1}$ Décsei Roland, ${ }^{2}$ Kujbus Márton, ${ }^{3}$ Fejes Levente, ${ }^{4}$ Papcsák Nóra, ${ }^{5}$ \\ Sziki Gusztáv Áron ${ }^{6}$ \\ Debreceni Egyetem Müszaki Kar. Debrecen, Magyarország \\ ${ }^{1}$ szanto.attila@eng.unideb.hu \\ ${ }^{2}$ roland.decsei@gmail.com \\ ${ }^{3}$ kujbusmarci@gmail.com \\ ${ }^{4}$ leventefejes1@gmail.com \\ ${ }^{5}$ papcsak.nora@gmail.com \\ ${ }^{6}$ szikig@eng.unideb.hu
}

\begin{abstract}
Thanks to technological development, and increasingly strict environmental regulations, electric and hybrid vehicles are playing an increasingly important role in road transport. An important part of these vehicles is the electric motor, of which several different types are applied in modern vehicles. To perform the simulation of these motors, it is important to measure their basic electromagnetic and dynamic characteristics, since they are usually not provided by the manufacturers. The above characteristics serve as the input parameters of the simulation program. For the above measurements, a complex measuring system is needed. This motor test bench is also suitable for the static and dynamic testing of the electric motors. In this publication the layout of our own developed test bench is presented.
\end{abstract}

Keywords: electric motor, measuring system, motor test bench, simulation.

\section{Összefoglalás}

A technológia fejlődésének, valamint a folyamatosan szigorodó környezetvédelmi előírásoknak köszönhetően, az elektromos és hibrid járművek egyre szélesebb körben terjednek el a közúti közlekedésben. Ezen járművek egyik fő alkotórésze a villanymotor, amelynek számos típusa létezik, és teljesít szolgálatot a modern járművekben. A motorok szimulációjának elvégzéséhez fontos az alapvető elektromágneses és dinamikai paramétereik ismerete, mely adatokat a gyártók legtöbbször nem adják meg. Így ezeket kísérleti úton kell meghatározni, melyhez egy összetett mérőrendszer szükséges. Az említetteken túl, egy ilyen motortesztpad alkalmas még a különböző típusú elektromos motorok statikus vagy dinamikus tesztelésére. Jelen publikációban az általunk fejlesztett tesztpad felépítését mutatjuk be.

Kulcsszavak: elektromos motor, mérörendszer, motortesztpad, szimuláció.

\section{Bevezetés}

Napjainkban a közúti közlekedésben egyre szélesebb körben alkalmazzák a különböző alternatív hajtású járművek. Ezek közül leginkább az elektromos és hibrid hajtásúak terjedtek el, köszönhetően az akkumulátorok, valamint az elektromos és hibrid rendszerek gyors fejlődésének. [1] Ezeknek a rendszereknek fontos része az 
elektromos motor, így ezek vizsgálata az egyetemi kutatásokban is fontos szerepet játszik.

A Debreceni Egyetem Müszaki Karán is több kutatócsoport foglalkozik korszerű jármühajtások vizsgálatával, modellezésével és szimulációjával. Az elért eredményeket egyebek mellett az alternatív hajtású járművek számára szervezett országos és nemzetközi versenyeken is kamatoztathatjuk. A tudatosabb tervezés és ezáltal az eredményesebb versenyzés érdekében Matlab/ Simulink-környezetben [2, 3] kifejlesztettünk egy járműdinamikai szimulációs programot, amely a jármű műszaki adataiból előállítja a jármű menetdinamikai függvényeit. A programot felhasználva optimalizálhatjuk a jármű, illetve a hajtáslánc műszaki jellemzőit egy adott versenyfeladathoz.

A szimulációs program fontos része a jármű hajtásláncának, ezen belül motorjának szimulációja. [4-7] Ahhoz, hogy a szimulációs programot le tudjuk futtatni, ismerni kell a villanymotorok alapvető elektromágneses és dinamikai paramétereit, karakterisztikáit. Ezeket a legtöbb esetben a gyártók nem közlik, így kísérleti úton kell őket meghatározni. Ehhez egy olyan mérőrendszerre (motorvizsgáló tesztpadra) van szükség, mely alkalmas különböző típusú, elektromos hajtásláncokban alkalmazott villanymotorok tesztelésére, paramétereinek, karakterisztikáinak meghatározására.

Jelen közleményben bemutatjuk az általunk fejlesztett mérőrendszer felépítését, részegységeit és működését.

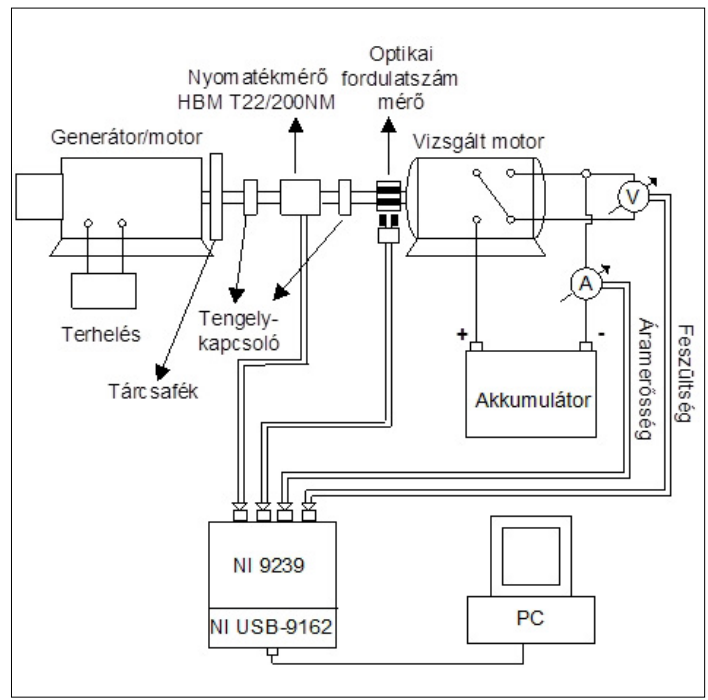

1. ábra. A mérörendszer elvi vázlata

\section{Mérőrendszer elvi vázlata}

A különböző típusú villanymotorok teszteléséhez, elektromágneses és dinamikai paramétereinek, karakterisztikáinak meghatározásához egy összetett mérőrendszerre van szükség. Fontos, hogy a különböző típusú motorokhoz és mérésekhez rugalmasan tudjuk változtatni a mérőelrendezés egyes paramétereit. A tervezett mérőelrendezés egyszerűsített elvi vázlatát az 1 . ábra szemlélteti, amely a kivitelezés során még bővülhet/módosulhat, illeszkedve az egyedi mérési feladatokhoz.

A mérőrendszer már meglévő és kipróbált részegységet a továbbiakban röviden ismertetjük.

\section{A mérőrendszer meglévő részegysé- geinek leírása}

A mérőrendszernek van számos olyan részegysége, amely nélkülözhetetlen a különböző típusú villanymotorokon történő mérések megfelelő minőségű és pontosságú elvégzéséhez. Emellett minden egyes részegységnek meg kell felelnie, több jól meghatározott technikai követelménynek. A következőkben ismertetjük a már meglévő részegységeket, és megadjuk azok rövid technikai leírását, valamint ismertetünk néhány általunk alkalmazott, valamint a továbbiakban tervezett megoldást.

\subsection{Merev, állítható pad, különböző típusú motorok rögzítésére}

A mérőrendszer felépítéséhez először is szükség van egy merev padra, amelyre rögzíthetjük a vizsgált és a terhelő motort (2. ábra). A vizsgált, különböző típusú villanymotorok radiális irányú elhelyezését a motorokhoz egyedileg gyártott rögzítő adapterek biztosítják. A tengelyirányú (valamint kismértékű vízszintes és függőleges irányú) állíthatóság a terhelő motor mozgatásával valósul meg. Az egytengelyűség pontos beállítása mérőóra,

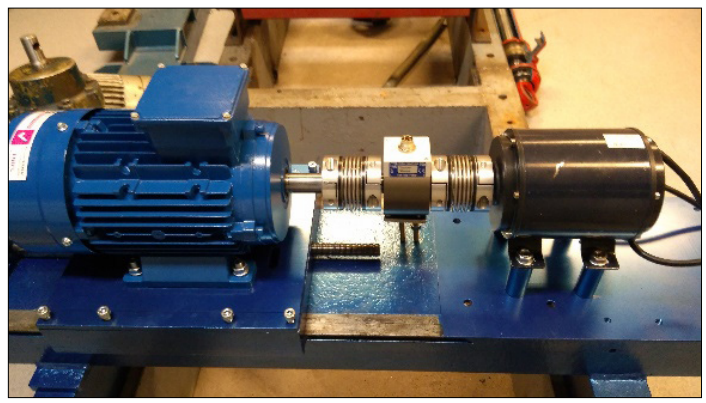

2. ábra. A mérőrendszer alapja, rajta a generátor és a vizsgált motor 
valamint lézeres tengelybeállító alkalmazásával történik.

Peremes motor rögzítéséhez egyedi adaptert kell gyártatni, amely a padhoz mereven rögzíthető. Ezáltal mind talpas, mind peremes motorok vizsgálhatók a mérőrendszerrel.

\subsection{Mérésadatgyưjtő kártya}

A mérésadatgyüjtő kártya egy National Instruments által gyártott, NI 9239-típusú, analóg-digitál (AD) modul, amelyet egy NI USB-9162 USB-adapteren keresztül kapcsolunk az adatrögzítő laptophoz. Ez 0-10V tartományban mér analóg feszültségjelet 4 földfüggetlen csatornán. A mérőkártya 24 bites felbontásban képes mintát venni $50 \mathrm{kHz}$ mintavételezési frekvencia mellett. Ezáltal megfelelő mennyiségű adat áll rendelkezésünkre bármely általunk tervezett mérési feladat esetén.

A fenti eszközhöz egy saját fejlesztésű, NI LabVIEW szoftverrel létrehozott, adatrögzítő programot használunk. A programban megadhatók az adatrögzítés főbb paraméterei, valamint élőben megjeleníthetjük az egyes csatornák jeleit. Tehát végül minden mért mennyiséget feszültségjelmérésre vezetünk vissza.

\subsection{Optikai elvü fordulatszámmérő eszköz}

A motor fordulatszámának méréséhez egy fényvisszaverődés elvén működő optikai ledszenzort alkalmazunk (típusa: ROS-P, Monarch Instrument). Az eszköz tápfeszültségét egy 6 V-os egyenáramú tápegység biztosítja, és 6 vagy $0 \mathrm{~V}$ kimenő feszültség jelet biztosít attól függően, hogy a forgó tárgyról visszaverődik-e fény az eszköz szenzorába, vagy nem. Ehhez a tárgy palástjára (pl. a motor tengelyének palástjára) fényvisszaverő csíkokat kell ragasztani, amelyeket a szenzor észlelni tud, ha azokról fény verődik vissza az eszközbe. A csíkok számának ismeretében, a feszültségjelek gyakoriságából számítható a fordulatszám.

\subsection{A nyomatékmérés}

Nyomatékmérésre egy HBM T22/200-típusú forgótengelyes nyomatékmérőt alkalmazunk. Ezt jelenleg kétféle méretű tengelykapcsolóval tudjuk a vizsgált, illetve terhelő motorhoz csatlakoztatni, attól függően, hogy mekkora nyomatékot ad le a vizsgált motorunk. A nyomatékmérőnek 200 Nm-es méréshatára van, és a mért nyomatékkal arányos feszültség jelet ad ki a 0-10V feszültségtartományban.

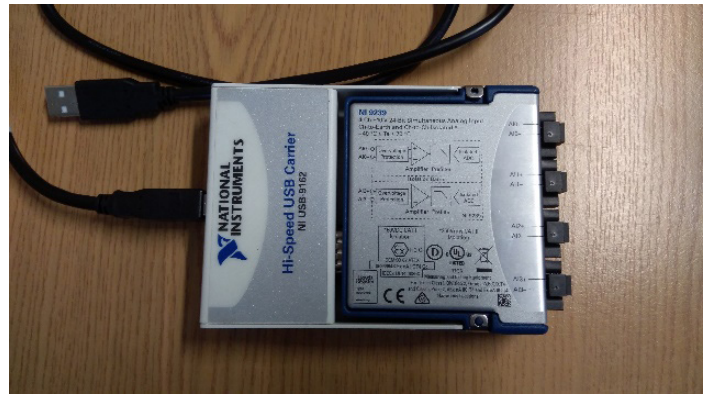

3. ábra. NI 9239 analóg-digitál (AD) modul az NI USB-9162 típusú USB-adapterrel

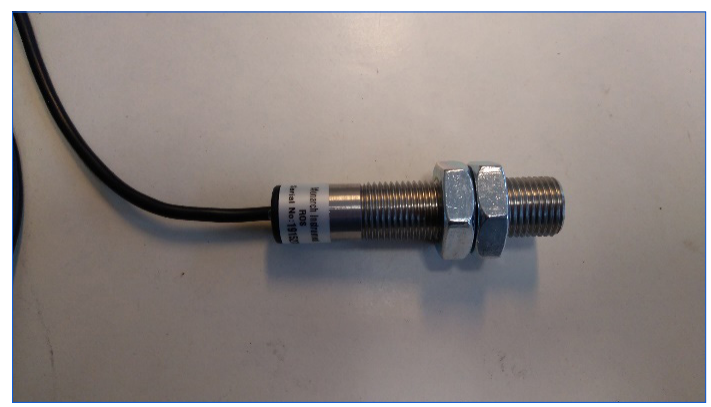

4. ábra. Az általunk használt fordulatszámmérö eszköz

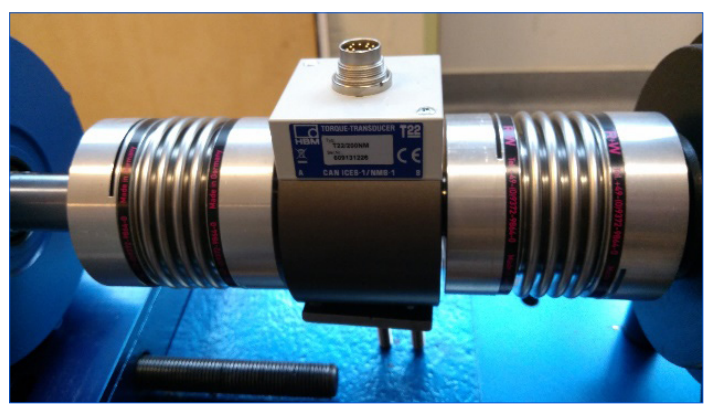

5. ábra. A forgótengelyes nyomatékmérö tengelykapcsolókkal

\subsection{Az áram- és feszültségmérés}

A motoron átfolyó áramerősséget egy sönt ellenálláson eső feszültségként mérjük, melynek ellenállása 0,0006 $\Omega$. Az akkumulátor kapocsfeszültségét - mivel az több, mint $10 \mathrm{~V}$, az NI 9239 eszköz nem tudja direktben mérni, ezért itt egy feszültségosztót alkalmazunk, 1:11 osztásaránnyal.

\section{4. Összefoglalás}

Jelen közleményben bemutattuk egy elektromos motorok mérésére, tesztelésére alkalmas, általunk kidolgozott mérőrendszer főbb részegységeit. Ezeket felhasználva fogjuk összeállítani a mé- 
rőrendszerünket, kiegészítve egy villamos kapcsolószekrénnyel, valamint az egyes villanymotorok, valamint a terhelő motor működtetéséhez szükséges eszközökkel (pl. transzformátor, frekvenciaváltó, motorvezérlő elektronika). Amint a mérőrendszer felépül, először tesztméréseket tervezünk végezni a rendszer kalibrálásához, majd a 2. ábrán látható BLDC-motoron végeznénk méréseket, meghatározva a motor szimulációjához szükséges bemenő elektromágneses és dinamikai paramétereket/karakterisztikákat.

\section{Köszönetnyilvánítás}

„Az innovációs és technológiai minisztérium únkp20-3 kódszámú új nemzeti kiválóság programjának a nemzeti kutatási, fejlesztési és innovációs alapból finanszírozott szakmai támogatásával készült.”

"A tanulmány alapjául szolgáló kutatást az innovációs és technológiai minisztérium által meghirdetett tématerületi kiválósági program (tkp2020-nka-04) támogatta."

\section{Szakirodalmi hivatkozások}

[1] Szántó A., Szíki G. Á.: Review of Modern Vehicle Powertrains and Their Modelling and Simulation in MATLAB/Simulink. International Journal of Engineering And Management Sciences / Műszaki és Menedzsment Tudományi Közlemények 5/2. (2020) 232-250.
[2] Szántó Attila et.al.: Jármúdinamikai szimuláció és optimalizáció. Műszaki Tudományos Közlemények, 9. (2018) 219-222.

https://doi.org/10.33895/mtk-2018.09.50

[3] Szántó A., Szíki G. Á., Hajdu S.: Dynamics Simulation of a Prototype Race Car Driven by Series Wound DC Motor in Matlab-Simulink. Acta Polytechnica Hungarica, 17/4. (2020) 103-122. https://doi.org/10.12700/APH.17.4.2020.4.6

[4] Szíki G. Á., Sarvajcz K., Kiss J., Gál,T., Szántó A., Gábora A., Husi G.: Experimental Investigation of a Series Wound Dc Motor for Modeling Purpose in Electric Vehicles and Mechatronics Systems. In: Measurement, 109. (2017) 111-118.

https://doi.org/10.1016/j.measurement.2017.05.055

[5] Hadziselimovic M., laznik M., Štumberger B., Zagradišnik I.: Magnetically Nonlinear Dynamic Model of a Series Wound DC Motor. Przeglad Elektrotechniczny (Electrical Review), R. $87 \mathrm{nr}$ $12 \mathrm{~b} / 2011$.

[6] Szíki G. Á., Szántó A., Mankovits T.: Dynamic Modelling and Simulation of a Prototype Race Car in MATLAB/Simulink Applying Different Types of Electric Motors. International Review Of Applied Sciences And Engineering, 2020. 1-7. https://doi.org/10.1556/1848.2020.00145

[7] Szántó Attila, Szántó András, Sziki G. Á.: Review of the Modelling Methods of Series Wound DC motors. Müszaki Tudományos Közlemények, 13. (2020)166-169. https://doi.org/10.33894/mtk-2020.13.31 